\title{
Multiple G Protein-Coupled Receptors Initiate Protein Kinase C Redistribution of GABA Transporters in Hippocampal Neurons
}

\author{
Matthew L. Beckman, ${ }^{1,2}$ Eve M. Bernstein, ${ }^{1}$ and Michael W. Quick ${ }^{1}$ \\ ${ }^{1}$ Department of Neurobiology and ${ }^{2}$ The Medical Scientist Training Program, University of Alabama at Birmingham, \\ Birmingham, Alabama 35294-0021
}

Neurotransmitter transporters function in synaptic signaling in part through the sequestration and removal of neurotransmitter from the synaptic cleft. A recurring theme of transporters is that many can be functionally regulated by protein kinase $\mathrm{C}(\mathrm{PKC})$; some of this regulation occurs via a redistribution of the transporter protein between the plasma membrane and the cytoplasm. The endogenous triggers that lead to PKC-mediated transporter redistribution have not been elucidated. G-proteincoupled receptors that activate PKC are likely candidates to initiate transporter redistribution. We tested this hypothesis by examining the rat brain GABA transporter GAT1 endogenously expressed in hippocampal neurons. Specific agonists of G-protein-coupled acetylcholine, glutamate, and serotonin receptors downregulate GAT1 function. This functional inhibition is dose-dependent, mimicked by PKC activators, and pre-

Plasma membrane GABA transporters are members of a large family of $\mathrm{Na}^{+}$-dependent neurotransmitter reuptake proteins, located on neurons and glia, that function in part to regulate neurotransmitter levels in the synaptic cleft. Not only can GABA transporters regulate neuronal signaling (Dingledine and Korn, 1985; Hablitz and Lebeda, 1985; Solis and Nicoll, 1992; Isaacson et al., 1993), but transporter function also can be regulated. Functional modulation, demonstrated for most members of the transporter family (for review, see Gegelashvili and Schousboe, 1997; Beckman and Quick, 1998), can occur through a variety of second messengers. These factors can exert their effects directly (e.g., by phosphorylation; Casado et al., 1993; Conradt and Stoffel, 1997; Huff et al., 1997; Ramamoorthy et al., 1998) or by regulating the interaction of the transporter with other nerve terminal proteins, such as syntaxin (Beckman et al., 1998).

A common feature of many transporters is functional regulation by protein kinase C (PKC) (Casado et al., 1993, Corey et al., 1994, Sato et al., 1995; Loo et al., 1996; Conradt and Stoffel, 1997; Huff et al., 1997; Qian et al., 1997; Apparsundaram et al., 1998b; Zhu et al., 1998). The effects of PKC occur in part through changes in the number of functional surface transporters (Qian et al., 1997; Quick et al., 1997; Davis et al., 1998). The majority of experiments demonstrating this effect have been performed on cloned transporters in heterologous expression systems using pharmacological agents that activate or inhibit PKC. Therefore,

Received Jan. 6, 1999; revised March 10, 1999; accepted March 16, 1999.

This work was supported by W. M. Keck Foundation Grant 931360 and National Institutes of Health Grant DA10509 (to M.W.Q.).

Correspondence should be addressed to Michael W. Quick, Department of Neurobiology, CIRC 446, University of Alabama at Birmingham, 1719 Sixth Avenue South, Birmingham, AL 35294-0021.

Copyright (C) 1999 Society for Neuroscience 0270-6474/99/190001-06\$05.00/0 vented by specific receptor antagonists and PKC inhibitors. Surface biotinylation experiments show that the receptormediated functional inhibition correlates with a redistribution of GAT1 from the plasma membrane to intracellular locations. These data demonstrate (1) that endogenous GAT1 function can be regulated by PKC via subcellular redistribution, and (2) that signaling via several different G-protein-coupled receptors can mediate this effect. These results raise the possibility that some effects of G-protein-mediated alterations in synaptic signaling might occur through changes in the number of transporters expressed on the plasma membrane and subsequent effects on synaptic neurotransmitter levels.

Key words: biotinylation; GAT1; hippocampus; neurotransmitter uptake; protein trafficking; seven-helix receptor

the physiological signals that trigger PKC-mediated transporter modulation in endogenous systems are not known.

Receptor-mediated signaling may be one such trigger. 5-HT transport can be increased (1) by adenosine receptor activation in basophilic leukemia cells (Miller and Hoffman, 1994) and (2) by histamine receptor activation in platelets (Launay et al., 1994). In astrocytes, glutamate transport is increased after glutamate application; the effect is prevented with kainate receptor antagonists (Gegelashvili et al., 1996). Signals mediated through G-proteincoupled receptors are a likely trigger for PKC-mediated neurotransmitter transporter regulation because (1) specific G-proteinmediated pathways result in PKC activation, and (2) such receptors are abundant on both neurons and glia. Support for this hypothesis comes from studies showing that the norepinephrine transporter expressed in a neuroblastoma cell line can be regulated by activation of muscarinic receptors (Apparsundaram et al., 1998b). Unfortunately, expression levels of the transporter in this system were too low to directly test whether modulation by muscarinic receptors was correlated with a redistribution of the

This article is published in The Journal of Neuroscience, Rapid Communications Section, which publishes brief, peerreviewed papers online, not in print. Rapid Communications are posted online approximately one month earlier than they would appear if printed. They are listed in the Table of Contents of the next open issue of JNeurosci. Cite this article as: JNeurosci, 1999, 19:RC9 (1-6). The publication date is the date of posting online at www.jneurosci.org.

http://www.jneurosci.org/cgi/content/full/3073 
$\mathbf{A}$

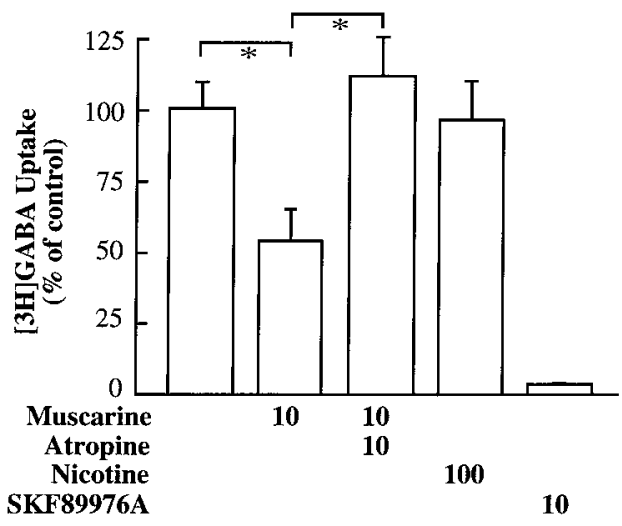

B

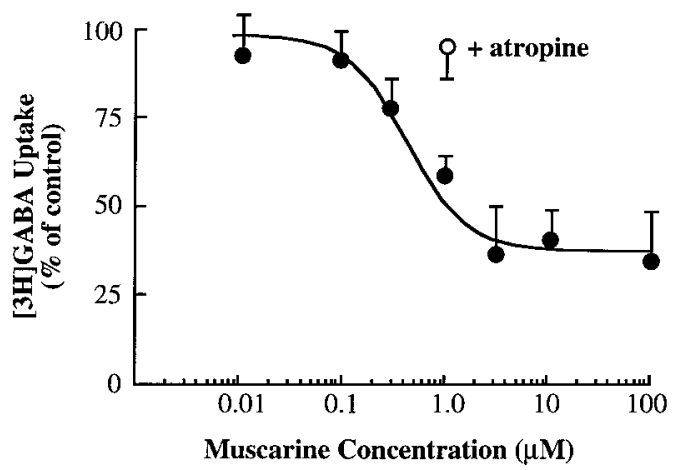

C

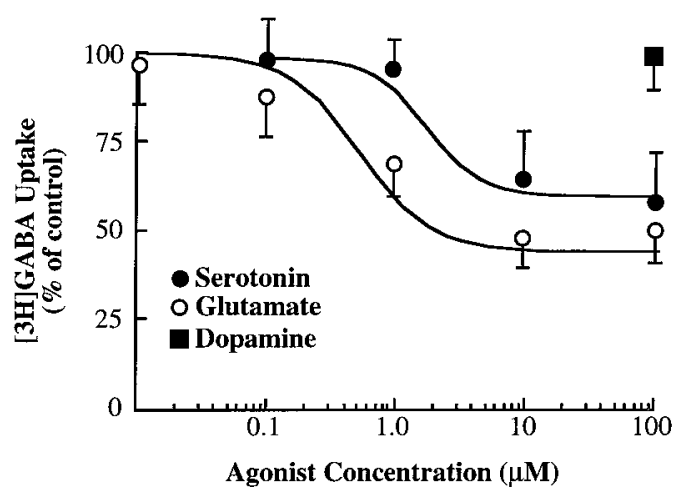

D

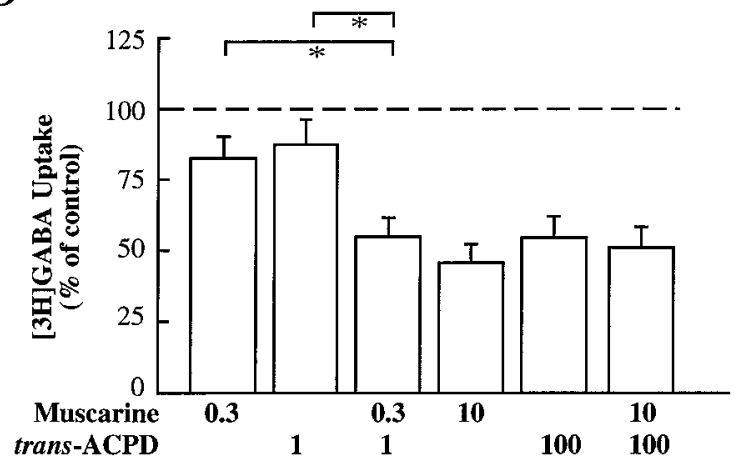

Figure 1. G-protein-coupled receptors regulate GABA transport in hippocampal cultures. $A$, Downregulation of GABA transporter GAT1 function by muscarinic receptor activation. Drug concentrations (micromolar) are shown below the abscissa; drugs were present for the duration of the assay. Data are from three experiments, four wells per condition per experiment. GABA uptake under control conditions ranged from 574 to $813 \mathrm{fmol} / \mathrm{min}$ per $\mathrm{mg}$ of protein. *Experimental conditions that resulted in a significant difference $(p<0.05)$ between groups. $B$, Muscarine inhibition of GABA transport is dose-dependent. Muscarine ( filled circles) was applied at the indicated concentrations. Addition of $10 \mu \mathrm{M}$ atropine (open circles) was included in some wells treated with $1 \mu \mathrm{M}$ muscarine. Data are from three experiments, three wells per condition per experiment. GABA uptake under control conditions was $521 \mathrm{fmol} / \mathrm{min}$ per $\mathrm{mg}$ of protein. C, Glutamate and serotonin also downregulate GABA transport. Glutamate (open circles), serotonin ( filled circles), and dopamine ( filled square) were applied at the indicated concentrations. Data are from two experiments, four wells per condition per experiment. Mean GABA uptake under control conditions was $457 \mathrm{fmol} / \mathrm{min}$ per $\mathrm{mg}$ of protein. $D$, Multiple receptors likely mediate decreases in GABA transport through the same mechanism. Drug concentrations (micromolar) are shown below the abscissa. Data are from two experiments, four to six wells per condition per experiment. Mean GABA uptake under control conditions was $761 \mathrm{fmol} / \mathrm{min}$ per mg of protein. *Experimental conditions that resulted in a significant difference $(p<0.05)$ between groups.

transporter. In the present report, we show that several G-protein-coupled receptors can regulate both GABA transporter function and its subcellular distribution in neurons that endogenously express these molecules.

\section{MATERIALS AND METHODS}

Cell culture. Primary hippocampal cultures were prepared from postnatal day $0-3$ rats by mincing tissue in $\alpha$-MEM supplemented with cysteine, glucose, and $100 \mathrm{U}$ papain. Tissue was incubated for $20 \mathrm{~min}$ at $37^{\circ} \mathrm{C}$, followed by gentle trituration, dilution, and plating. To obtain pure neuronal cultures, mixed cultures were treated for $48 \mathrm{hr}$ with $10 \mu \mathrm{M}$ cytosine arabinoside (Sigma, St. Louis, MO); treatment was initiated 24 hr after plating.

$\left[{ }^{3} H\right] G A B A$ uptake assays. Neurons were rinsed three times in $1 \times$ HBSS and allowed to equilibrate for $10 \mathrm{~min}$ in the final wash. Drugs of interest were applied at the start of the assay and remained present throughout (15 min). GABA was added to initiate the assay. The final $\left[{ }^{3} \mathrm{H}\right] \mathrm{GABA}$ concentration of the assay solution was $100 \mathrm{~nm}$; the total GABA concentration of the assay solution was $30 \mu \mathrm{M}$. The assay was terminated by rapidly rinsing the cells three times with $1 \times$ HBSS, followed by solubilization in $300 \mu \mathrm{l}$ of $0.005 \%$ SDS at $37^{\circ} \mathrm{C}$ for $2 \mathrm{hr}$. Aliquots were used for scintillation counting and to determine protein concentrations. Statistical analyses of the uptake data were performed using SPSS. Two-sample comparisons were made using $t$ tests; multiple comparisons were made using one-way ANOVAs followed by Tukey's honestly significant difference post hoc test.
Biotinylation experiments. Biotinylation experiments were performed essentially as described (Qian et al., 1997; Davis et al., 1998). Cells were grown in $100 \mathrm{~mm}$ tissue culture dishes to $80 \%$ confluence. The cells were rinsed twice with $37^{\circ} \mathrm{C}$ PBS $/ \mathrm{Ca} / \mathrm{Mg}$ (in mm: $138 \mathrm{NaCl}, 2.7 \mathrm{KCl}, 1.5$ $\mathrm{KH}_{2} \mathrm{PO}_{4}, 9.6 \mathrm{Na}_{2} \mathrm{HPO}_{4}, 1 \mathrm{MgCl}_{2}$, and $0.1 \mathrm{CaCl}_{2}, \mathrm{pH}$ 7.4). The cells were next incubated with $2 \mathrm{ml}$ of a solution containing $1 \mathrm{mg} / \mathrm{ml}$ sulfoNHS biotin (Pierce, Rockford, IL) in PBS/Ca/ Mg for 20 min at $4^{\circ} \mathrm{C}$ with gentle shaking. Unless otherwise noted, drugs of interest were applied at room temperature for $5 \mathrm{~min}$ before addition of biotin. The biotinylation solution was removed by two washes in $\mathrm{PBS} / \mathrm{Ca} / \mathrm{Mg}$ plus $100 \mathrm{~mm}$ glycine and quenched in this solution by incubating the cells at $4^{\circ} \mathrm{C}$ for $45 \mathrm{~min}$ with gentle shaking. The cells were lysed with $1 \mathrm{ml}$ of radioimmunoprecipitation assay (RIPA) buffer (in mM: 100 Tris-Cl, pH 7.4, $150 \mathrm{NaCl}, 1$ mM EDTA, $1 \%$ Triton X-100, $1 \%$ sodium deoxycholate, $0.1 \%$ SDS, 1 $\mu \mathrm{g} / \mathrm{ml}$ leupeptin, $1 \mu \mathrm{g} / \mathrm{ml}$ aprotinin, and $250 \mu \mathrm{M}$ PMSF) at $4^{\circ} \mathrm{C}$ for 60 $\mathrm{min}$. The cell lysates were centrifuged at $20,000 \times g$ at $4^{\circ} \mathrm{C}$ for $60 \mathrm{~min}$. The supernatant fractions $(300 \mu \mathrm{l})$ were incubated with an equal volume of immunopure immobilized monomeric avidin beads (Pierce) at room temperature for $60 \mathrm{~min}$. The beads were washed three times with RIPA buffer, and adsorbed proteins were eluted with SDS sample buffer (62.5 mM Tris-Cl, pH 6.8, 2\% SDS, and $100 \mathrm{~mm} \beta$-mercaptoethanol) at room temperature for $30 \mathrm{~min}$.

Western analyses. Analysis was performed on aliquots (1) taken before incubation with beads (total cell lysate), (2) of the supernatant fraction after adsorption and centrifugation (intracellular fraction), and (3) of the bead eluate (biotinylated fraction). Western blotting was performed using anti-GAT1 antibody 346J (Beckman et al., 1998) as described 


\begin{tabular}{|c|c|c|c|c|c|}
\hline Agonist & Antagonist & $\begin{array}{l}\text { [Agonist] } \\
(\mu \mathrm{M})\end{array}$ & $\begin{array}{l}\text { [Antagonist] } \\
(\mu \mathrm{M})\end{array}$ & Predicted action at applied concentrations & $\begin{array}{l}\text { GABA uptake } \\
(\% \text { of control })^{a}\end{array}$ \\
\hline Muscarine & & 1 & & Activate muscarinic receptors, all types & $61 \pm 7(6)^{b}$ \\
\hline Muscarine & atropine & 1 & 10 & Inhibit muscarinic receptors, all types & $94 \pm 9(4)$ \\
\hline Muscarine & 4-DAMP & 1 & 0.01 & Inhibit M1, M3, and M5 muscarinic receptors & $103 \pm 13(2)$ \\
\hline Muscarine & himbacine & 1 & 0.1 & Inhibit M2 and M4 muscarinic receptors & $66 \pm 9(2)$ \\
\hline Nicotine & & 100 & & Activate nicotinic receptors, all types & $90 \pm 12(2)$ \\
\hline Glutamate & & 100 & & Activate glutamate receptors, all types & $47 \pm 8(2)$ \\
\hline trans-ACPD & & 100 & & Activate metabotropic receptors, all types & $51 \pm 11(3)$ \\
\hline trans-ACPD & MCPG & 100 & 100 & Inhibit metabotropic receptors, all types & $110 \pm 21(2)$ \\
\hline L-AP-4 & & 100 & & Activate group III metabotropic receptors & $91 \pm 14(2)$ \\
\hline DHPG & & 100 & & Activate group I metabotropic receptors & $52 \pm 4(2)$ \\
\hline Serotonin & & 100 & & Activate serotonin receptors, all types & $63 \pm 7(2)$ \\
\hline$\alpha$-ME-5-HT & & 0.5 & & Activate serotonin type 2 receptors & $70 \pm 14(2)$ \\
\hline Dopamine & & 100 & & Activate dopamine receptors, all types & $101 \pm 6(2)$ \\
\hline
\end{tabular}

${ }^{a}$ Control refers to cultures measured in the absence of receptor agonists and/or antagonists.

${ }^{b}$ Numbers in parentheses refer to the number of experiments (three to five wells per condition per experiment).

(Corey et al., 1994), and visualized using ECL reagents (Amersham, Arlington Heights, IL). Monoclonal anti-actin antibodies (Sigma) were used to normalize protein levels. Immunoreactive bands were scanned and quantitated with ImageQuant (Molecular Dynamics, Sunnyvale, CA).

\section{RESULTS}

To test the possibility that G-protein-coupled receptors are an endogenous trigger for GABA transporter regulation, we applied the G-protein-coupled acetylcholine receptor agonist muscarine to hippocampal neurons and examined its effect on GABA uptake (Fig. 1A). Neurons treated with a saturating concentration of muscarine showed an approximately twofold decrease in GABA uptake. This decrease was mediated predominantly by the rat brain GABA transporter GAT1, because application of SKF89976A (Larsson et al., 1988), a GABA transporter antagonist with relatively high affinity for GAT1 compared with other GABA transporters, reduced GABA uptake in these cultures by $>90 \%$. The muscarine-induced decrease in transport was prevented by co-application of atropine, a muscarinic acetylcholine receptor antagonist. Nicotine, a nicotinic acetylcholine receptor agonist with little effect on muscarinic acetylcholine receptors, had no effect on GABA uptake. The effect on GABA uptake was muscarine concentration-dependent (Fig. 1B), with a halfmaximal effective concentration of $\sim 820 \mathrm{~nm}$. Taken together, these data suggest that muscarinic acetylcholine receptors can mediate alterations in GAT1 function in hippocampal neurons.

To see whether other receptors might also affect GABA transporter function, we repeated the uptake studies in the presence of various known transmitters that have receptors in the hippocampus (Fig. 1C). Both serotonin and glutamate induced decreases in GABA uptake in a dose-dependent manner; dopamine had no effect. These data are consistent with the hypothesis that receptors that are coupled to G-proteins that lead to PKC activation can regulate GABA transport. Dopamine receptors, which couple to G-proteins that do not lead to PKC activation, failed to have an effect.

Of course, muscarine, glutamate, and serotonin also activate receptors other than those linked to increases in PKC. To determine specific receptor classes that alter GABA uptake, we performed additional experiments using specific receptor agonists and antagonists (Table 1). As also shown in Figure 1, the nonspecific muscarinic acetylcholine receptor agonist muscarine de- creased GABA uptake. This decrease was blocked by atropine and 4-diphenylacetoxy- $N$-methyl-piperidine (4-DAMP), a muscarinic acetylcholine receptor antagonist that has high affinity for the M1, M3, and M5 muscarinic receptor subtypes. The decrease was not prevented by himbacine, a receptor antagonist that has high affinity for the M2 and M4 receptor subtypes. These data support the idea that GABA uptake can be regulated by the M1, M3, and M5 receptor subtypes; these muscarinic subtypes specifically lead to PKC activation.

Glutamate also exerts its effects through G-protein-coupled receptors (Table 1). trans-(1S,3R)-1-amino-1,3-cyclopentanedicarboxylic acid (ACPD), a metabotropic glutamate receptor agonist, decreased GAT1 function; this decrease was prevented by co-application of methyl-4-carboxyphenylglycine (MCPG), a metabotropic receptor antagonist. Application of $S$-3,5dihydroxyphenylglycine (DHPG), a specific agonist of group I metabotropic receptors, mimicked the trans-ACPD effects. L-AP-4, a specific agonist of group III metabotropic receptors, did not affect GABA uptake. Because group I metabotropic receptors are specifically linked to PKC activation, glutamate also exerts its effects on GABA uptake via receptors that activate PKC. The same is true of serotonin, because $\alpha$-methyl(ME)-5-HT, a specific agonist of $\mathrm{PKC}$-activating $5-\mathrm{HT}_{2}$ receptors, decreased GABA uptake.

One question is whether these multiple receptor systems can act synergistically to regulate GAT1 function. To test this hypothesis, subsaturating concentrations of muscarine $(0.3 \mu \mathrm{M})$ and trans-ACPD $(1 \mu \mathrm{M})$, applied individually and together, were used to decrease GABA uptake (Fig. 1D). Although application of either agonist resulted in a decrease in GABA transport, coapplication further reduced GAT1 function. A related question is whether these different transmitter systems are exerting their effects on the same population of transporters. For example, the various receptors may be located on different subpopulations of neurons. In this scenario, using saturating agonist concentrations at each of two different receptors should lead to a greater reduction in GABA uptake compared with the results obtained stimulating either receptor alone. In the presence of both muscarine $(10 \mu \mathrm{M})$ and trans-ACPD $(100 \mu \mathrm{M})$, the decrease in uptake was comparable with that seen with either agonist alone. Taken together, these data suggest that different G-protein-coupled recep- 
A

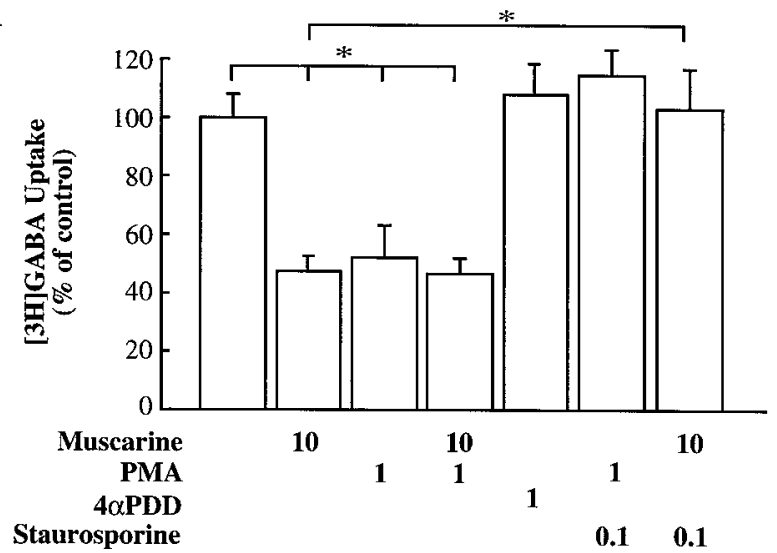

B

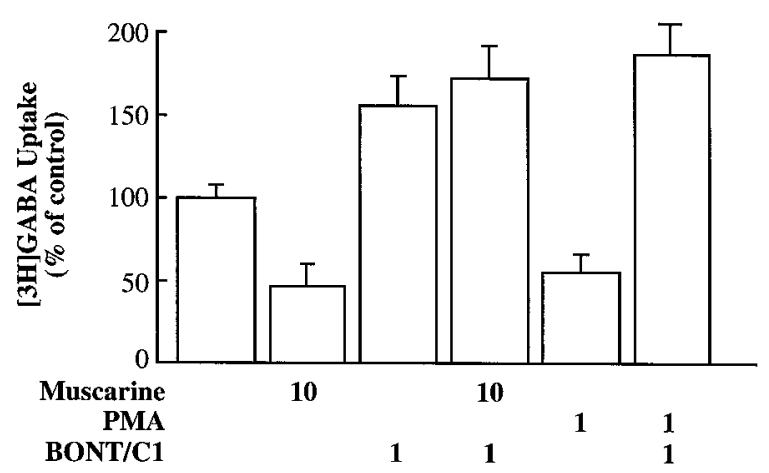

Figure 2. Receptor-mediated regulation of GABA transport occurs via protein kinase C. Drug concentrations (micromolar) are shown below the abscissa; drugs were present for the duration of the assay. *Experimental conditions that resulted in a significant difference $(p<0.05)$ between groups or compared with control. $A$, Regulation of GABA transport by muscarine in the presence of PKC activators and inhibitors. Data are from three experiments, four to six wells per condition per experiment. GABA uptake under control conditions ranged from 461 to $733 \mathrm{fmol} / \mathrm{min}$ per $\mathrm{mg}$ of protein. $B$, Botulinum toxin prevents the muscarine-mediated decrease in GABA transport. Data are from three experiments, four to six wells per condition per experiment. GABA uptake under control conditions ranged from 583 to $645 \mathrm{fmol} / \mathrm{min}$ per $\mathrm{mg}$ of protein.

tors can act together to affect the same population of GABA transporters.

Are the receptor-mediated decreases in GAT1 function PKCdependent? To answer this question, we examined muscarinemediated changes in GABA transport in the presence of activators and inhibitors of PKC (Fig. 2A). Consistent with the idea that $\mathrm{PKC}$ and muscarine are acting through the same pathway, application of the PKC-activating phorbol ester PMA mimicked the muscarine-induced effect. Furthermore, co-application of both compounds had no synergistic effect on transport. The inactive phorbol ester $4 \alpha$-phorbol 12,13-didecanoate had no effect on transport, suggesting a PKC-mediated effect of PMA. Stronger support for the idea that the muscarine-induced decrease in GABA transport is PKC-mediated comes from experiments involving the PKC inhibitor staurosporine. Co-application of staurosporine reversed both the PMA-induced decrease and the muscarine-induced decrease in GAT1 function.

Previously, we showed that PKC can mediate its reduction in
GABA transport, at least in part, by increasing the association of the transporter with syntaxin $1 \mathrm{~A}$; specific cleavage of syntaxin $1 \mathrm{~A}$ by botulinum toxin $\mathrm{C} 1(\mathrm{BONT} / \mathrm{C} 1)$ prevents the $\mathrm{PKC}$-mediated decrease in GAT1 function (Beckman et al., 1998). Thus, if muscarinic receptor activation decreases GABA transport via $\mathrm{PKC}$, cleavage of syntaxin $1 \mathrm{~A}$ by $\mathrm{BONT} / \mathrm{C} 1$ should prevent the decrease. Application of BONT/C1 caused an increase in GAT1 function (Fig. $2 B$ ); co-application of PMA or muscarine failed to alter this BONT/C1-mediated increase in GABA transport, consistent with the idea that G-protein-coupled receptors can exert their effects on transport via PKC and syntaxin. Figure $2 B$ also makes another important point. Transport through GAT1 is voltage-dependent, and some of the decrease in uptake seen with receptor activation could be attributable to changes in membrane potential (e.g., via G-protein effects on ion channels). The evidence that, in the presence of BONT/C1, uptake is increased to similar values in the absence or presence of muscarine argues against a decrease in uptake attributable to a decrease in membrane potential. The evidence that PKC exerts its effects on transport in cells under voltage-clamp conditions (Qian et al., 1997; Quick et al., 1997) also argues against an effect attributable to changes in membrane potential.

Previous studies in heterologous expression systems or in immortalized cell lines showed that PKC can exert some of its effects by causing a redistribution of transporters between the plasma membrane and the cytoplasm. To test this hypothesis in primary hippocampal neurons endogenously expressing the GABA transporter, and to provide further support for the hypothesis that the receptor-activated effects on transport are PKC-mediated, we performed saturation analyses on GABA uptake and surface biotinylation experiments on GAT1 protein (Fig. 3). Untreated and muscarine-treated neurons were subjected to uptake experiments at various GABA concentrations. Saturation analysis demonstrated that muscarine induced a reduction in the maximum velocity of transport, with no change to the apparent affinity of GABA for the transporter (Fig. 3A). These data are consistent with a reduction in the number of functional transporters and comparable with previous data showing PMA modulation of GABA transport (Beckman et al., 1998).

More direct evidence for a redistribution of transporters in response to receptor activation comes from surface biotinylation experiments. GAT1 immunoreactivity after biotinylation of surface proteins was examined in untreated neurons and neurons treated with either muscarine or PMA (Fig. $3 B$ ). As shown both in the representative immunoblot and in the bar graph of densitometry measurements (Fig. 3B, bottom panel), untreated neurons show a majority of GAT1 immunoreactivity in the biotinylated (surface) fraction. Incubation of cells with muscarine or PMA caused a decrease in surface GAT1 immunoreactivity and an increase in the amount of GAT1 immunoreactivity in the nonbiotinylated (intracellular) fraction. Comparable data were seen when neurons were treated with trans-APCD (data not shown). The immunoblot data correlate well with the functional changes in uptake, suggesting that PKC-activating G-proteins may exert their effect on transport, at least in part, by causing a redistribution of GABA transporters. The evidence that PMA and muscarine produced comparable effects lends support to the idea that muscarine mediates its effects through PKC. In addition, the redistribution occurred in the presence of cycloheximide (data not shown), suggesting that the modulation is attributable to a redistribution of transporters rather than to synthesis of new transporter protein. 
A

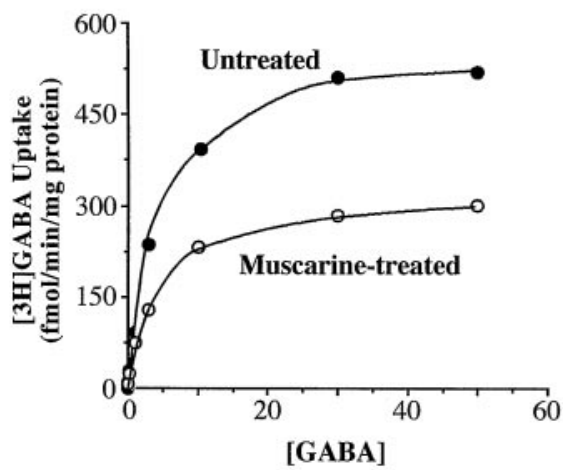

B
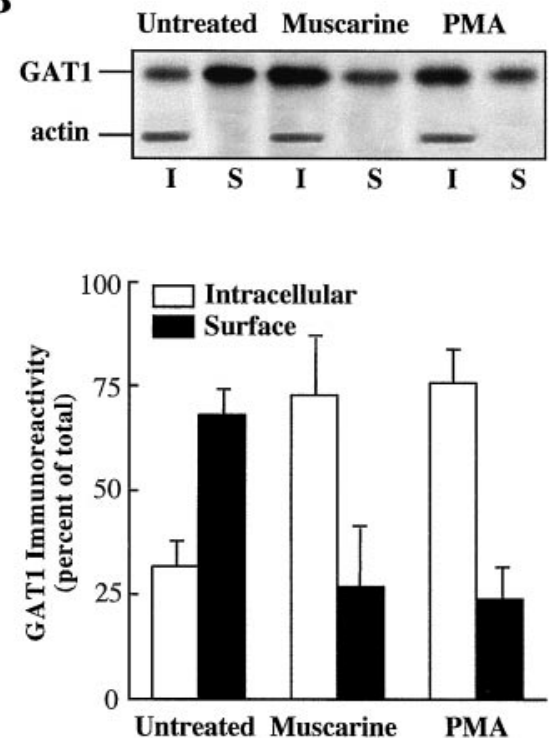

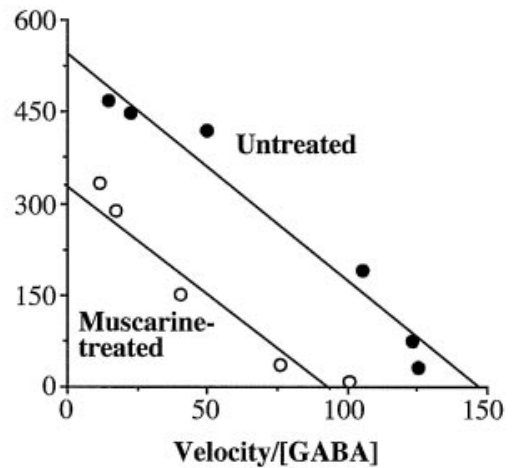

C
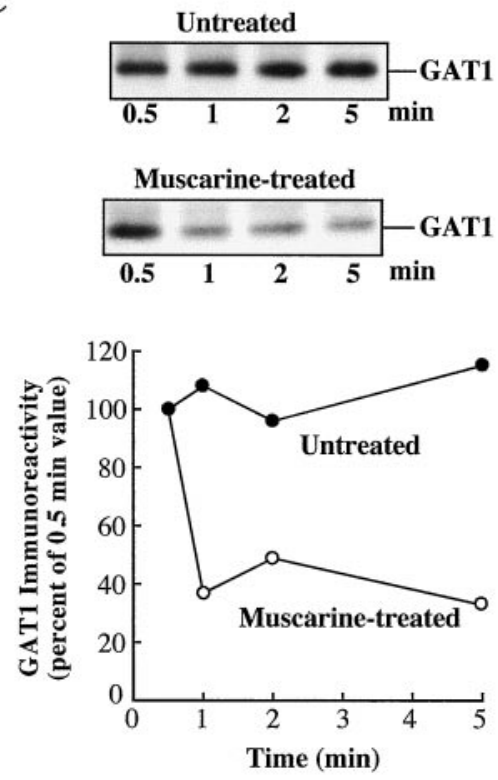

Figure 3. Receptor activation causes a redistribution of GAT1. A, Saturation analysis of muscarine-mediated changes in transport. GABA uptake in hippocampal neurons was determined at various GABA concentrations in the absence (filled circles) or presence (open circles) of $10 \mu \mathrm{M}$ muscarine (left panel). An Eadie-Hofstee transformation of these data is shown in the right panel. Data shown are from one experiment, six wells per concentration. The experiment was repeated twice with similar results. $B$, Changes in surface GAT1 immunoreactivity as assessed by surface biotinylation. Representative immunoblot shows GAT1 immunoreactivity from nonbiotinylated $(I)$ and biotinylated $(S)$ fractions for cultures untreated or treated with muscarine $(10 \mu \mathrm{M})$ or PMA $(1 \mu \mathrm{M})$. Quantitation of intracellular (open bars) and surface ( filled bars) GAT1 immunoreactivity is shown in the graph. Data, plotted as a percentage of total immunoreactivity, are from densitometric measurements made on three separate immunoblots. $C$, Time course of muscarine-mediated GAT1 redistribution. Neurons were treated with saline (untreated) or $10 \mu \mathrm{M}$ muscarine for $1 \mathrm{~min}$. Biotinylating reagent was then added $0.5,1,2$, or 5 min after muscarine treatment. The representative immunoblots show GAT1 immunoreactivity for the biotinylated fraction at these time points. Quantitation of GAT1 immunoreactivity is shown in the graph for neurons in control solution (filled circles) or muscarine (open circles).
The contribution of this form of transporter regulation to cell signaling will in part be determined by the rate at which receptormediated redistribution of the transporter occurs. To determine this, we examined the amount of GAT1 immunoreactivity in the biotinylated fraction of a cell treated with muscarine and then biotinylated at $0.5,1,2$, and 5 min after removal of muscarine (Fig. 3C). In untreated control cultures, the amount of GAT1 immunoreactivity in the biotinylated fraction remained constant over the 5 min period; in the muscarine-treated cells, the amount of GAT1 immunoreactivity was reduced by $50 \%$ within 1 min of the end of muscarine treatment. These results are consistent with the evidence that muscarine reduces the number of surface GAT1 molecules and demonstrate that the redistribution occurs rapidly after muscarine treatment. The time course of the decrease in surface biotinylation in muscarine-treated cells was comparable with the time course of uptake inhibition measured in parallel cultures (data not shown).

\section{DISCUSSION}

G-proteins transduce signals from cell surface receptors for neurotransmitters and other molecules to intracellular second messengers and ion channels (Simon et al., 1991; Hepler and Gilman, 1992; Conklin and Bourne, 1993). One subset of G-proteins (the $\mathrm{G} \alpha_{\mathrm{q}}$ family) is responsible for coupling receptor-mediated signals to phospholipase $\mathrm{C}$ activation; in turn, phospholipase $\mathrm{C}$ catalyzes hydrolysis of phosphotidyl 4,5-bisphosphate to create inositol trisphosphate and diacylglycerol. Inositol trisphosphate causes release of $\mathrm{Ca}^{2+}$ from intracellular stores, and diacylglycerol activates PKC (Berridge, 1993; Smrcka and Sternweis, 1993; Kuang et al., 1996). In the present report, we show that activation of three different receptors that couple to this pathway can reduce uptake of GABA in hippocampal neurons that endogenously express these molecules. Furthermore, we show that the reduction in uptake is PKC-mediated and is correlated with a redistribution of the GABA transporter GAT1 from the plasma membrane to intracellular locations.

The evidence that botulinum toxin $\mathrm{C} 1$ prevents the receptormediated inhibition of GABA uptake suggests that syntaxin $1 \mathrm{~A}$ may play a role in this process. We have shown previously that syntaxin 1A regulates GABA uptake in heterologous expression systems and that this effect is regulatable by PKC (Beckman et al., 1998). However, we do not have evidence, to date, that syntaxin $1 \mathrm{~A}$ also plays a role in the subcellular redistribution of the transporter. The evidence that $\mathrm{PKC}$ can regulate some transporters directly (Ramamoorthy et al., 1998) suggests that multiple mechanisms may play a role in both transport inhibition and transporter redistribution. Furthermore, we do not know the extent to which net transporter internalization is responsible for the decrease in uptake; our data only demonstrate that the time 
course of these two events is similar after receptor activation. Interestingly, maximal muscarinic receptor-mediated effects on GABA transport and GAT1 transporter redistribution occurred within $\sim 1$ min. This is faster than the muscarinic receptor effects on norepinephrine transporters expressed in neuroblastoma cells ( $230 \mathrm{~min}$; Apparsundaram et al., 1998a). Although this difference maybe attributable to transporter differences in response to $\mathrm{PKC}$, an intriguing possibility is that in hippocampal neurons, the endogenous receptors, G-proteins, protein kinases, and transporters form a tightly linked complex that results in efficient transporter mobilization.

A physiological role for GABA transporters has been elucidated in experiments involving specific GABA uptake inhibitors. These inhibitors prolong responses mediated by $\mathrm{GABA}_{\mathrm{A}}$ receptors (Isaacson et al., 1993), and both prolong and increase responses mediated by G-protein-coupled $\mathrm{GABA}_{\mathrm{B}}$ receptors (Dingledine and Korn, 1985; Solis and Nicoll, 1992; Isaacson et al., 1993). GABA transporters also play a physiological role in retinal horizontal cells in which efflux through the transporter is a principal mode of neurotransmitter release (Schwartz, 1987). Receptor-mediated modulation of neurotransmitter transport may add to the repertoire by which transmitter-mediated activity can regulate neuronal signaling. Because receptor-mediated modulation results in a decrease in the number of plasma membrane transporters, several mechanisms may play a role in altering the neuronal signal. At slow synapses (see Lester et al., 1994), the decrease in transmitter transport, per se, will alter postsynaptic receptor-mediated responses. At fast synapses, signals will be modulated because of a reduction in the number of diff usion sinks (i.e., transporter binding sites) available for transmitter sequestration (Diamond and Jahr, 1997). In addition, some transporters exhibit both nonstoichiometric, substrate-dependent ionic fluxes and substrate-independent leak currents (Sonders and Amara, 1996) that will be reduced because of transporter redistribution.

\section{REFERENCES}

Apparsundaram S, Galli A, DeFelice LJ, Hartzell HC, Blakely RD (1998a) Acute regulation of norepinephrine transport: I. Protein kinase C-linked muscarinic receptors influence transport capacity and transporter density in SK-N-SH cells. J Pharmacol Exp Ther 287:733-743.

Apparsundaram S, Schroeter S, Giovanetti E, Blakely RD (1998b) Acute regulation of norepinephrine transport: II. PKC-modulated surface expression of human norepinephrine transporter proteins. J Pharmacol Exp Ther 287:744-751.

Beckman ML, Quick MW (1998) Neurotransmitter transporters: regulators of function and functional regulation. J Membr Biol 164:1-10.

Beckman ML, Bernstein E, Quick MW (1998) Protein kinase C regulates the interaction between a GABA transporter and syntaxin 1A. J Neurosci 18:6103-6112.

Berridge MJ (1993) Inositol trisphosphate and calcium signalling. Nature 361:315-325.

Casado M, Bendahan A, Zafra F, Danbolt NC, Aragón C, Giménez C, Kanner BI (1993) Phosphorylation and modulation of brain glutamate transporters by protein kinase C. J Biol Chem 268:27313-27317.

Conklin BR, Bourne HR (1993) Structural elements of G $\alpha$ subunits that interact with $\mathrm{G} \beta \gamma$, receptors, and effectors. Cell 73:631-641.

Conradt M, Stoffel W (1997) Inhibition of the high-affinity brain glutamate transporter GLAST-1 via direct phosphorylation. J Neurochem 68:1244-1251.

Corey JL, Davidson N, Lester HA, Brecha N, Quick MW (1994) Protein kinase $\mathrm{C}$ modulates the activity of cloned $\gamma$-aminobutyric acid transporter expressed in Xenopus oocytes via regulated subcellular redistribution of the transporter. J Biol Chem 269:14759-14767.

Davis KE, Straff DJ, Weinstein EA, Bannerman PG, Correale DM,
Rothstein JD, Robinson MB (1998) Multiple signaling pathways regulate cell surface expression and activity of the excitatory amino acid carrier 1 subtype of glu transporter in C6 glioma. J Neurosci 18:2475-2585.

Diamond JS, Jahr CE (1997) Transporters buffer synaptically released glutamate on a submillisecond time scale. J Neurosci 17:4672-4687.

Dingledine R, Korn SJ (1985) Gamma aminobutyric acid uptake and the termination of inhibitory synaptic potentials in the rat hippocampal slice. J Physiol (Lond) 366:387-409.

Gegelashvili G, Schousboe A (1997) High affinity glutamate transporters: regulation of expression and activity. Mol Pharmacol 52:6-15.

Gegelashvili G, Civenni G, Racagni G, Danbolt NC, Schousboe I, Schousboe A (1996) Glutamate receptor agonists up-regulate glutamate transporter GLAST in astrocytes. NeuroReport 8:261-265.

Hablitz JJ, Lebeda FJ (1985) Role of uptake in $\gamma$-aminobutyric acid (GABA)-mediated responses in guinea pig hippocampal neurons. Cell Mol Neurobiol 5:353-371.

Hepler JR, Gilman AG (1992) G proteins. Trends Biochem Sci 17:383-387.

Huff RA, Vaughan RA, Kuhar MJ, Uhl GR (1997) Phorbol esters increase dopamine transporter phosphorylation and decrease transport Vmax. J Neurochem 68:225-232.

Isaacson JS, Solis JM, Nicoll RA (1993) Local and diffuse synaptic actions of GABA in the hippocampus. Neuron 10:165-175.

Kuang Y, Wu Y, Smrcka A, Jiang H, Wu D (1996) Identification of a phospholipase $C \beta 2$ region that interacts with $G \beta \gamma$. Proc Natl Acad Sci USA 93:2964-2968.

Larsson OM, Falch E, Krogsgaard-Larsen P, Schousboe A (1988) Kinetic characterization of inhibition of gamma-aminobutyric acid uptake into cultured neurons and astrocytes by 4,4-diphenyl-3-butenyl derivatives of nipecotic acid and guvacine. J Neurochem 50:818-823.

Lester HA, Mager S, Quick MW, Corey JL (1994) Permeation properties of neurotransmitter transporters. Annu Rev Pharmacol Toxicol 34:219-249.

Launay JM, Bondoux D, Oset-Gasque MJ, Emami S, Mutel V, Haimart M, Gespach C (1994) Increase of human platelet serotonin uptake by atypical histamine receptors. Am J Physiol 266:R526-R536.

Loo DD, Hirsch JR, Sakar HK, Wright EM (1996) Regulation of the mouse retinal taurine (TAUT) by protein kinases in Xenopus oocytes. FEBS Lett 392:250-254.

Miller KJ, Hoffman BJ (1994) Adenosine $A_{3}$ receptors regulate serotonin transport via nitric oxide and cGMP. J Biol Chem 269:27351-27356.

Qian Y, Galli A, Ramamoorthy S, Risso S, DeFelice LJ, Blakely RD (1997) Protein kinase C activation regulates human serotonin transporters in HEK-293 cells via altered cell surface expression. J Neurosci $17: 45-57$.

Quick MW, Corey JL, Davidson N, Lester HA (1997) Second messengers, trafficking-related proteins, and amino acid residues that contribute to the functional regulation of the rat brain GABA transporter GAT1. J Neurosci 17:2967-2979.

Ramamoorthy S, Giovanetti E, Qian Y, Blakely RD (1998) Phosphorylation and regulation of antidepressant-sensitive serotonin transporters. J Biol Chem 273:2458-2466.

Sato K, Adams R, Betz H, Schloss P (1995) Modulation of a recombinant glycine transporter (GLYT1b) by activation of protein kinase C. J Neurochem 65:1967-1973.

Schwartz EA (1987) Depolarization without calcium can release $\gamma$-aminobutyric acid from a retinal neuron. Science 238:350-355.

Simon MI, Strathmann MP, Gautam N (1991) Diversity of G proteins in signal transduction. Science 252:802-808.

Smrcka AV, Sternweis PC (1993) Regulation of purified subtypes of phosphatidylinositol-specific phospholipase $\mathrm{C} \beta$ by $\mathrm{G}$ protein $\alpha$ and $\beta \gamma$ subunits. J Biol Chem 268:9667-9674.

Solis JM, Nicoll RA (1992) Pharmacological characterization of $\mathrm{GABA}_{\mathrm{B}}$-mediated responses in the CA-1 region of the rat hippocampal slice. J Neurosci 12:3466-3472.

Sonders MS, Amara SG (1996) Channels in transporters. Curr Opin Neurobiol 6:294-302.

Zhu MY, Blakely RD, Apparsundaram S, Ordway GA (1998) Downregulation of the human norepinephrine transporter in intact 293hNET cells exposed to desipramine. J Neurochem 70:1547-1555. 